\title{
ON THE OVERREGULATION OF THE BODY TEMPERATURE AGAINST COOLING IN RABBITS
}

\author{
SHOJI SAITO \\ Department of Pharmacology, School of Medicine, \\ Keio University
}

(Received on June 13, 1957)

\section{INTRODUCTION}

It has been already recognized by Koyama(1), Kimura(2), Ogata(3) and some others that when unfastened rabbits were removed from a room at normal temperature into a cooler at about $0^{\circ} \mathrm{C}$, the rectal temperature is not lowered but raised remarkably. It has been confirmed also by the auther(4).

Though Ogata(3) has named the rise of the body temperature due to cooling the initial rise of it by cooling and explained that the initial rise might ber induced by change of intake and outtake of the body heat and of the thermal distribution in the body, but $\mathrm{Abe}^{(5)}$ has explained that the rise of the rectal temperature due to cooling was induced by overregulation of the body temperature against cooling and Kimura(2) has proved that the rise of the rectal temperature due to cooling would be caused chiefly by excitation of the extrapyramidal body temperature regulating centres (named by $\mathrm{Abe}^{(5)}$ ) which would cause the first chemical body temperature regulation by inducing an increase of the heat production in the muscle tissues.

Then by what grade of the low environmental temperature the rise of the rectal temperature would be caused? And how the rise of the rectal temperature due to cooling would be influenced by disturbance of the chemical body temperature regulation against heating?

In order to clarify these questions the following experiments were performed.

\section{METHODS}

In these experiments rabbits of approximately $2 \mathrm{~kg}$ body weight were used. The rectal temperature was measured by a nonstay mercury thermometer, inserted into the rectum over $6 \mathrm{~cm}$ for over 3 minutes.

To cool rabbits an electric cooler in which the air can be cooled down to 
$-20^{\circ} \mathrm{C}$ was used.

\section{EXPERIMENTAL RESULTS}

I. Cooling experiments of unfastened rabbits

On different days the same rabbit was removed from a room at various temparature into a cooler at various lower temperature and the rectal temperature was measured for 4 hours after the removal.

It was noticed that the low environmental temperature which would induce a rise of the rectal temperature in rabbits would vary somewhat by the fact whether the animal was previously in a room at usual or at much higher environmental temperature.

a. Cooling experiments of unfastened rabbits which have been in a room at $18 \sim 20^{\circ} \mathrm{C}$.

When the unfastened rabbit was removed from a room at $18 \sim 20^{\circ} \mathrm{C}$ into a cooler at $7^{\circ} \mathrm{C}$, the rectal temperature did not change noticeably for 4 hours after the removal (Fig. 1).

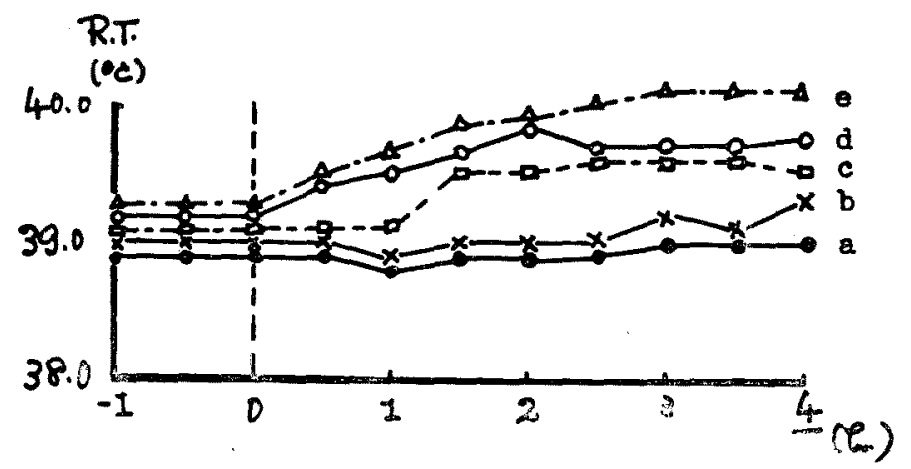

Fig. 1 Change of the rectal temperature caused by cooling of various grade in rabbits (No. 1 ).

Rabbit, male, body weight
Room temperature
Cooling temperature

$$
\begin{array}{rr} 
& 1.98 \mathrm{~kg} \\
& 18 \sim 20^{\circ} \mathrm{C} \\
\mathrm{a}: & 7^{\circ} \mathrm{C} \\
\mathrm{b}: & 6^{\circ} \mathrm{C} \\
\mathrm{c}: & 4^{\circ} \mathrm{C} \\
\mathrm{d}: & 0^{\circ} \mathrm{C} \\
\mathrm{e}: & -15^{\circ} \mathrm{C}
\end{array}
$$

But when the same animal was removed from the same temperature room into a cooler at $6^{\circ} \mathrm{C}$, the rectal temperature rose slightly about $0.3^{\circ} \mathrm{C}$ within 4 hours, though it did not change noticeably for about 2 hours after the removal. And when the same animal was removed from the same temperature room into a cooler at $4^{\circ} \mathrm{C}$, the rectal temperature rose $0.4 \sim 0.5^{\circ} \mathrm{C}$ within $3 \sim 4$ hours, though it did not show noticeable change for about one hour after the removal. 
When the same animal was removed from the same temperature room into a cooler at $0^{\circ} \mathrm{C}$ or at $-15^{\circ} \mathrm{C}$, the rectal temperature began to rise immediately after the removal and it showed $0.6 \sim 1.0^{\circ} \mathrm{C}$ higher within $3 \sim 4$ hours.

But the rise of the rectal temperature did not always oceur by removal of the same animal from the same temperature room into a cooler at $-20^{\circ} \mathrm{C}$.

According to these experimental results the rectal temperature of the rabbit which was previously in a room at $18 \sim 20^{\circ} \mathrm{C}$ would be raised by cooling the animal below $6^{\circ} \mathrm{C}$. And the lower the cooling grade, the faster and the higher the rectal temperature rose, though the rise of it would not always be induced by cooling below $-20^{\circ} \mathrm{C}$.

b. Cooling experiments of unfastened rabbits which was in a room at over $30^{\circ} \mathrm{C}$.

In summer when room temperature was over $30^{\circ} \mathrm{C}$ the same cooling experiments as above mentioned were performed and following results were obtained.

When the animal was removed from a room at over $30^{\circ} \mathrm{C}$ into a cooler at $7^{\circ} \mathrm{C}$, the rectal temperature rose about $0.6^{\circ} \mathrm{C}$ higher within $2 \sim 3$ hours, though it did not change noticeably for one hour after the removal (Fig. 2).

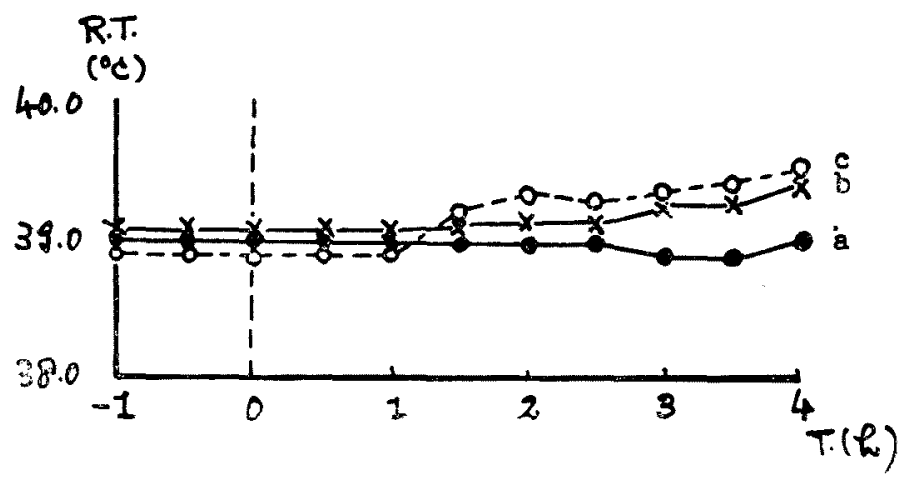

Fig. 2 Change of the rectal temperature caused by cooling of various grade in rabbits (No. 2).

$$
\begin{array}{lr}
\text { Rabbit, male, body weight } & 2.13 \mathrm{~kg} \\
\text { Room temperature } & 30 \sim 32^{\circ} \mathrm{C} \\
\text { Cooling temperature } & \mathrm{a}: 9^{\circ} \mathrm{C} \\
& \mathrm{b}: 8^{\circ} \mathrm{C} \\
& \mathrm{c}: 7^{\circ} \mathrm{C}
\end{array}
$$

And when the same animal was removed from the same high temperature room into a cooler at $8^{\circ} \mathrm{C}$, the rectal temperature rose $0.3 \sim 0.4^{\circ} \mathrm{C}$ higher within $3 \sim 4$ hours, though it did not change for one hour after the removal.

But when the same animal was removed from the same high temperature room into a cooler at $9^{\circ} \mathrm{C}$, the rectal temperature did not show noticeable change 
for 4 hours after the removal.

Accordingly the rectal temperature of rabbits which have been previously in a room at over $30^{\circ} \mathrm{C}$ would rise by cooling the animal below $8^{\circ} \mathrm{C}$.

Then it would be comprehended that in rabbits which was previously in much higher environmental temperature the rise of the rectal temperature due to cooling would be induced by comparatively mild cooling.

\section{Cooling experiments of unfastened bilaterally vagotomized rabbits.}

Honda ${ }^{(6)}$ has reported that for the rise of the body temperature due to cooling the body temperature regulation against heating would be induced physiologically.

Then the rise of the rectal temperature due to cooling ought to be caused more easily by disturbing the body temperature regulation against heating.

According to $A b e^{(5)}$ the chemical body temperature regulation against a rise of the body temperature (the temperature of the internal carotid blood) would be induced by excitation of the parasympathetic centres in Nucleus caudatus, which would cause decrease of the heat production in the liver through the pathway of the vagal nerves.

Then the same cooling experiments as above mentioned were performed on unfastened bilaterally vagotomized rabbits; and control experiments were performed on the same animal.

a. Cooling experiments of unfastened bilaterally vagotomized rabbits which

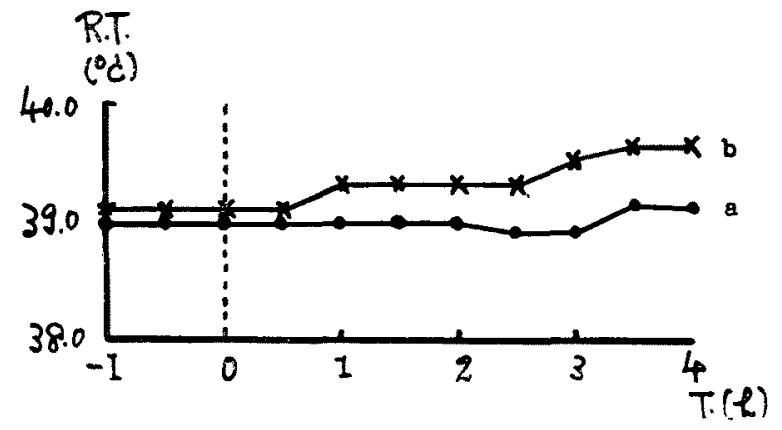

Fig. 3 Change of the rectal temperature caused by cooling at $7^{\circ} \mathrm{C}$ before and after cutting both vagi in the same rabbit (No. 1).

$$
\begin{array}{cr}
\text { Rabbit, male, body weight } & 2.35 \mathrm{~kg} \\
\text { Room temperature } & 18 \sim 19^{\circ} \mathrm{C} \\
\text { Cooling temperature } & 7^{\circ} \mathrm{C} \\
\text { a... The rectal temperature before } \\
\text { cutting both vagi } \\
\text { b. . The rectal temperature after } \\
\text { cutting both vagi }
\end{array}
$$


was in a room at $18 \sim 20^{\circ} \mathrm{C}$.

It was ascertained in an unfastened normal rabbit which had been in a room at $18 \sim 20^{\circ} \mathrm{C}$ that the rectal temperature did not show any noticeable change by removing the animal from the room into a cooler at $7^{\circ} \mathrm{C}$ for 4 hours. And next day of the experiment in the same animal, both vagi were cut off and later the recovery of the rectal temperature was made sure in this unfastened bilaterally vagotomized animal in a room at $18 \sim 20^{\circ} \mathrm{C}$; and then it was removed from the room into a cooler at $7^{\circ} \mathrm{C}$. At this time the rectal temperature rose gradually $0.3 \sim 0.5^{\circ} \mathrm{C}$ higher within $2 \sim 3$ hours after the removal (Fig. 3).

b. Cooling experiments of unfastened bilaterally vagotomized rabbits which have been in a room at over $30^{\circ} \mathrm{C}$.

It was ascertained also in an unfastened normal rabbit which had been in a room at over $30^{\circ} \mathrm{C}$ that the rectal temperature does not change noticeably by removing it from the room in a cooler at $9^{\circ} \mathrm{C}$ for 4 hours. And next day of the experiment the same unfastened, bilaterally vagotomized rabbit was removed from the room at over $30^{\circ} \mathrm{C}$ into a cooler also at $9^{\circ} \mathrm{C}$. At this time the rectal temperature rose gradually about $0.5^{\circ} \mathrm{C}$ higher within $3 \sim 4$ hours after the removal (Fig. 4).

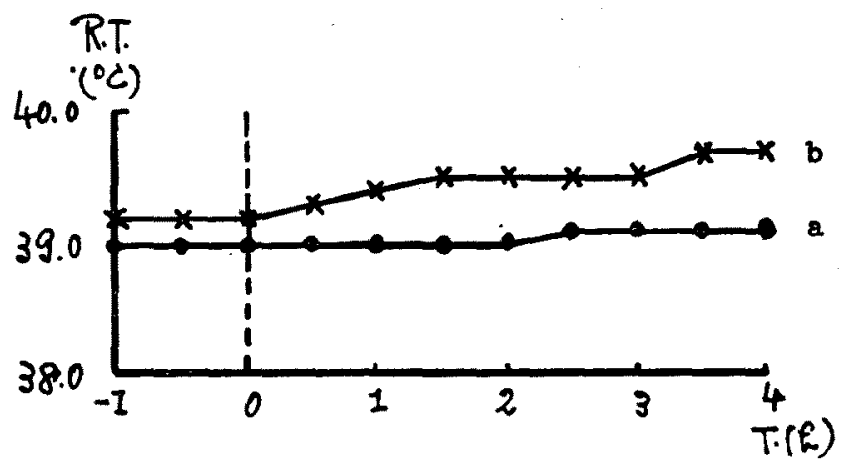

Fig. 4 Change of the rectal temperature caused by cooling at $9^{\circ} \mathrm{C}$ before and after cutting both vagi in the same rabbit (No. 2).

$$
\begin{array}{lr}
\text { Rabbit, male, body weight } & 1.92 \mathrm{~kg} \\
\text { Room temperature } & 30 \sim 32^{\circ} \mathrm{C} \\
\text { Cooling temperature } & 9^{\circ} \mathrm{C} \\
\text { a... The rectal temperature before cutting } \\
\text { both vagi } \\
\text { b... The rectal temperature after cutting } \\
\text { both vagi }
\end{array}
$$

According to these experimental results in unfastened bilaterally vagotomized rabbits the rise of the rectal temperature due to cooling ought to be induced by weaker cooling. 


\section{SUMMARY AND CONCLUSION}

1. In rabbits which were in the moderate temperature room the rise of the rectal temperature due to cooling would be induced by cooling below $6^{\circ} \mathrm{C}$, while in rabbits in the higher temperature (over $30^{\circ} \mathrm{C}$ ) room it would be caused by somewhat weaker cooling (below $8^{\circ} \mathrm{C}$ ).

2. The lower the cooling grade, the faster and the higher the rectal temperature rises due to cooling, though the rise of it would not be always induced by cooling below $-20^{\circ} \mathrm{C}$.

Then the rise of the rectal temperature due to cooling ought to depend on the cooling grade and duration.

3. The rise of the rectal temperature due to cooling would be induced by weaker cooling in rabbits with both vagi cut off than in normal rabbits.

Accordingly the rise of the rectal temperature due to cooling should be prevented in some degree by the body temperature regulation against heating which would be caused physiologically; in other words, the rise of the rectal temperature would appear when overregulation of the body temperature against cooling surpassed the body temperature regulation for heating which would be induced physiologically to prevent the rise of the body temperature.

It is evident then that the overregulation of the body temperature against cooling must have been already caused by weaker cooling than that which would cause a rise of the rectal temperature.

\section{REFERENCES}

1. Koyama, G.: Journal of exp. Pharmacology, 15:218-248, 1938. (in Japanese)

2. Kimura, K.: unpublished (see Abe).

3. Ogata, K.: Cooling and the Body Temperature Regulation, Nanjo-Shoten, Osaka 1949. (in Japanese)

4. Saito, S.: Folia Pharmacologica Japonica, 44:12, 1949. (in Japanese)

5. Abe, K.: Review of Japanese Physiology, 2:69-95, 1943. (in Japanese)

6. Honda, T.: Folia Pharmacologica Japonica, 67:40, 1951. (in Japanese) 